\title{
Association Between Self-Discipline Towards Grade Point Average Among Medical Students
}

\author{
Artha Budi Susila Duarsa ${ }^{1 *}$, Irwan Syuhada ${ }^{1}$, Ayu Anulus ${ }^{1}$ \\ ${ }^{1}$ Faculty of Medicine, Al-Azhar Islamic University \\ "Corresponding author. Email: arthasusiladuarsa@gmail.com
}

\begin{abstract}
Self-discipline is the ability to prevent something that could lead to harmful effects of unhealthy excesses. Self-discipline has implications, particularly among medical students, for improving academic performance. The purpose of this study was to examine the association between self-discipline towards grade point average (GPA) among medical students. This was a cross-sectional study conducted at Al-Azhar Islamic University, Mataram, West Nusa Tenggara. A total of 241 medical students was enrolled in this study. The dependent variable was the GPA. The independent variable was self-discipline. Self-discipline data were obtained from the Minnesota Multiphasic Personality Inventory-2 (MMPI-2) test at the first medical school admission process. GPA data were obtained from the academic section. The data were analyzed using the Chi-square test. The study showed that GPA among medical students was mostly average (45.64\%), good $(44.81 \%)$, and low $(9.54 \%)$. MMPI-2 test reported that students were mostly had good self-discipline $(85.06 \%)$. From the Chi-square test, it was found that the GPA was associated with self-discipline among medical students at AlAzhar Islamic University, Mataram $(\mathrm{p}=0.010)$. In conclusion, the grade point average among medical students is associated with self-discipline. Further study is required using the data from the MMPI-2 test.
\end{abstract}

Keywords: Self-discipline, Grade Point Average, MMPI-2.

\section{INTRODUCTION}

Students, including medical students, as the nation's successor candidates are the assets of a country in realizing its goals. Medical students are prospective doctors who will lead and develop the country especially in the health sector. Medical students must have characters in accordance with the value of Pancasila which is the basic value of the Indonesian nation. As a national education goal, medical students must also have the religious and cultural values [1].

At a university, especially at a medical educational program, it is necessary to carry out an assessment that can describe the student's mastery of the material being taught, to be able to produce competent and professional graduates. In Indonesia, especially at the Faculty of Medicine, Al-Azhar Islamic University, the assessment of the learning process is carried out in accordance with the standards set by the government. One of the assessments of the learning process that is carried out is an assessment of student learning outcomes. This learning outcome assessment is the minimum criterion that students must meet at every stage of the learning process in a tertiary institution [2]. This learning outcomes are shown in a scoring system called Grade Point Average (GPA).
Students' achievement are often associated with many factors coming from either outside or inside individual. One of factors that come from inside of students itself is self-discipline. According to the Ministry of National Education (2010), self-discipline is an action that shows orderly behavior and obeys various provisions and regulations [1]. Self-discipline is closely related to the rules and norms in nation. A person who has self-discipline is willing to implement and apply the prevailing rules and norms with his own awareness without coercion. In the medical education, which generally has the main objective of achieving human welfare, self-discipline is needed, because doctors are a noble profession with high ethical standard, discipline, moral, and a sense of humanity.

In a higher education, self-discipline is found to influence and relate to various aspects, i.e., student achievement [3]. Medical faculty is intended to ensure that graduate students have a professional attitude in their field and, in this case, become trained doctors in accordance with the Indonesian Doctors Competency Requirements [4].

A research found that self-discipline can be used for predicting academic performance among adolescents [5]. However the study focused on exploring the relationship between self-discipline and GPAs among medical students are rare. Therefore, this research was focused on 
exploring the relationship between self-discipline and GPA among medical students at Faculty of Medicine, AlAzhar Islamic University as an effort to produce competent and professional doctor.

\section{SUBJECTS AND METHOD}

\subsection{Study Design}

This was a cross-sectional study design conducted at the Faculty of Medicine, Al-Azhar Islamic University, Mataram, West Nusa Tenggara, Indonesia, from June to August 2020.

\subsection{Population and Sample}

The population in this study were all students of the Faculty of Medicine, Al-Azhar Islamic University, Mataram, West Nusa Tenggara, Indonesia. A total of 288 students with valid results of MMPI-2 was selected for this study.

\subsection{Study Variables}

The independent variable was self-discipline and the dependent variable was GPA among medical students. Self-discipline variable was obtained from MPPI-2 test. The test was include twelve psychological items including self-discipline item.

\subsection{Data Analysis}

Data on self-discipline and GPA among medical students obtained from the academic bioethics field of Faculty of Medicine, Al-Azhar Islamic University. The data were analyzed using bivariate analysis, as known as Chi-square, to examine the relationship between selfdiscipline and GPA.

\subsection{Research Ethic}

Research ethic included a consent form, anonymity, confidentiality, and ethical due diligence. Ethical clearance in this study obtained from the Ethics Committee of the Faculty of Medicine, Al-Azhar Islamic University with number: 026 / EC / FK-06 / UNIZAR / VIII / 2020.

\section{RESUlts}

The GPA results among medical students in this study were presented in the Figure 1. The student's GPA average from the 2016 academic year was 2.80 . Student ${ }^{\star} \mathrm{s}$ GPA average from the 2017 academic year was lower than the 2016 academic year. In the 2017 academic year, the student's GPA average was 2.66. In the 2018 academic year the GPA average was 2.49 , and in the 2019 academic year was 2.51 .

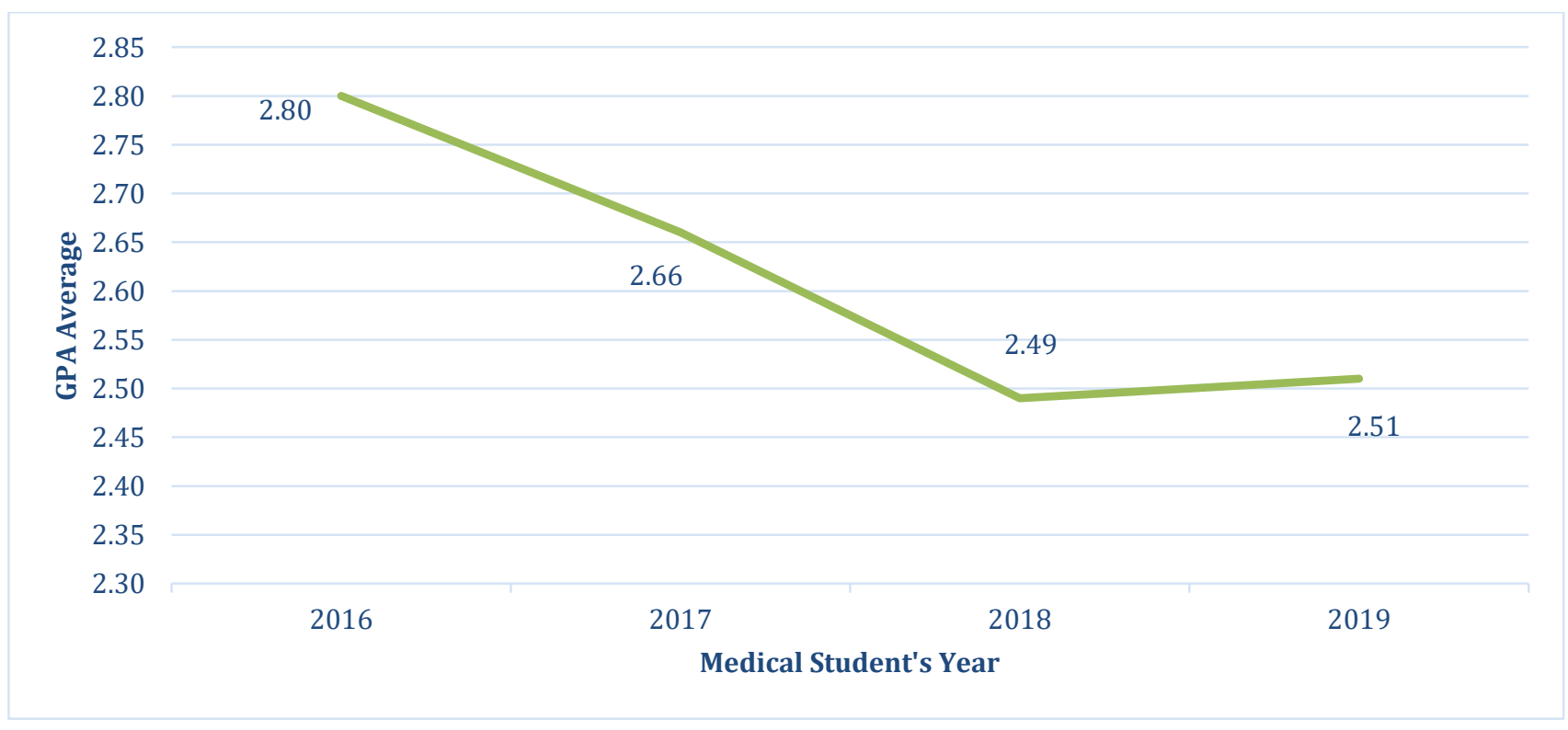

Figure 1. The GPA's average among medical students of the Faculty of Medicine, Al-Azhar Islamic University from 2016-2019 
Table 1. Characteristics of Study Subjects

\begin{tabular}{|l|l|l|l|}
\hline \multicolumn{1}{|c|}{ No CHARACTERISTICS } & \multicolumn{2}{c|}{ PERCENT } \\
\hline GPA & \multicolumn{1}{|c|}{ n } & \\
\hline 1. & Good & 108 & 44.81 \\
\hline 2. & Moderate & 110 & 45.64 \\
\hline 3. & Low & 23 & 9.54 \\
\hline Self-dicpiline & Good & 205 & 85.06 \\
\hline 1. & Low & 36 & 14.94 \\
\hline 2. & &
\end{tabular}

Table 2. The results of bivariate analysis using Chi-square

\begin{tabular}{|c|c|c|c|c|c|c|c|}
\hline \multirow{3}{*}{ Variable } & \multicolumn{4}{|c|}{ Self-discipline } & \multirow{2}{*}{\multicolumn{2}{|c|}{ Total }} & \multirow{3}{*}{$\mathrm{p}$} \\
\hline & \multicolumn{2}{|r|}{ Good } & \multicolumn{2}{|r|}{ Low } & & & \\
\hline & $\mathrm{N}$ & $\%$ & $\mathrm{~N}$ & $\%$ & $\mathrm{~N}$ & $\%$ & \\
\hline $\begin{array}{l}\text { GPA } \\
\text { Good } \\
\end{array}$ & 212 & 99.07 & 21 & 8.71 & 241 & 100 & 0.010 \\
\hline Low & 6 & 2.49 & 2 & 0.82 & & & \\
\hline
\end{tabular}

The Table 1, showed that most of students had moderate GPA (45.64\%), and only a few had low GPA $(9.54 \%)$.

The Table 2, showed that total of 212 medical students $(99.07 \%)$ had good self-discipline and good GPA. Total of 21 medical students $(8.71 \%)$ had low selfdiscipline and good GPA. Total of 6 medical students $(2.49 \%)$ had good self-discipline and low GPA. Total of 2 medical students $(0.82 \%)$ had low self-discipline and low GPA. Bivariate analysis of this reported that there was a relationship between self-discipline and GPA among medical students, and it was statistically significant (0.010).

\section{Discussion}

Medical education is a complex educational program. Doctors are expected to become professionals who can be helpful for their community. Therefore, in medical education there are elements and competency standards that a doctor must have. These competencies consist of various interrelated aspects which are contained in the Indonesian Doctor Competency Standards (SKDI). These elements include: the foundation of personality; mastery of knowledge and skills; the ability to work; attitude; and behavior in work according to the level of expertise based on the knowledge and skills mastered, understanding the rules of social life according to the choice of expertise in work [6].
To assess student's learning outcomes in order to achieve the objectives of learning, it is necessary to use a standardized assessment system. Based on regulations from the Ministry of Education and Culture of the Indonesian Republic, higher education institutions in Indonesia used GPA as a rating system to assess student learning achievement at the end of the study program. Most of the medical students in the Faculty of Medicine, Al-Azhar Islamic University had average (45.64\%) and good $(44.81 \%)$. There were only a couple of students with a low GPA $(9.54 \%)$. This can be affected by various aspects and factors that are interrelated with one another.

The results of this study shown that self-discipline was related with GPA. Several studies have shown that GPA were affected and correlated by various factors. Study conducted by Saputra (2015) was found that factors such as material, method of delivering material, tutor or lecturer, facility and infrastructure, as well as factor originating the student themselves had affected the student achievement (Saputra \& Lisiswanti, 2015). A research performed by Riyani (2012) also shows that the student's learning outcome can be influenced by at least 13 variables, i.e. learning objective, teaching content, instrument, motivation, teaching and learning process, system, resource, assessment, student interaction, environment, health and talent [8].

Factors related to student achievement consist of two major parts, namely internal factors, and external factors. The internal factor was the factor that came from the learning participant itself, in this case, the student. The internal factor consists of physical factors and 
psychological factors i.e., intelligence, interest, talent, and motivation. Meanwhile, external factors were the factors that came from the outside of the student, including family environmental factors (parents, home atmosphere, family economic conditions) and school environmental factors (teachers or teaching staff, supporting tools or media, school building conditions, curriculum).

The level of student discipline was also found to be related to student achievement. Suwanto in Sunarsi (2018) stated that discipline is an attitude of respect and appreciation and obedience to applicable regulations, both written and unwritten regulations [9]. This is close to the context of the discipline that is related to the educational regulations and standards that have been set and used by universities in the learning process of students in higher education.

A study conducted by Gani (2018) was also found that discipline was associated with student achievement among the Maritime Academy students [3]. Sunarsi (2018) research was also showed that discipline was positively related to student achievements [9]. This is consistent with the results found in this study.

The finding in this study differs from the result of Zimmerman's (2014) study. In Zimmerman the selfdiscipline was found to be not significantly predict the student's achievement [10]. The results difference can be caused by the different method used in measuring selfdiscipline item among the students. This study was used MMPI-2 to assess the students' self-discipline items.

In this study, the level of self-discipline among medical students in the Faculty of Medicine, Al-Azhar Islamic University was measured using an instrument known as the 2nd edition of the Minnesota Multiphasic Personality Inventory (MMPI) Test (MMPI-2). The MMPI test aims to determine early on the personality and psychological tendencies of each student of Faculty of Medicine, Al-Azhar Islamic University, Mataram, West Nusa Tenggara, Indonesia (FK UNIZAR Bioethics Guide, 2019).

The Minnesota Multiphasic Personality Inventory was already used in more than 50 countries and has more than 100 translation languages (Hebrew, Mandarin, Dutch, Russian, Spanish, Indonesian, Japanese, Italian, German, and others). Indonesian edition of MMPI test was first developed by WM Roan, Yul Iskandar, and R. Salan in 1973. However, this adaptation is still deemed inaccurate due to language problems that are not straightforward and the relationship between values and different cultures. Then an adaptation was carried out and was resulted in the second edition of the Indonesian MMPI by Syamsuddin et al. in 1982 [11].

In the MMPI-2 test, there were various items of student psychological potential, one of which was selfdiscipline. In this study, it was found that most medical students had a good level of discipline $(85.06 \%)$. It was found that there was an association between selfdiscipline and GPA after conducting statistical tests on the relationship between discipline and GPA among medical students in the Faculty of Medicine, Al-Azhar Islamic University using the Chi-square test. The findings in this study were supported by other studies which also showed an association between self-discipline discipline and the student's GPA $[3,9,12]$.

Besides self-discipline, several factors were also found to be related to students' achievement. Students' achievement was found to be significantly related to selfregulation and self-regulated learning [10,13]. However, this study only focused on self-discipline. Therefore the further study is needed to assess the relationship between factors that related to students' achievement.

\section{CONCLUSION}

The authors conclude that the self-discipline among medical students in the Faculty of Medicine, Al-Azhar Islamic University were associated with GPA. However, this study was not analyzed the factor that affects selfdiscipline among students. Further study is needed to analyze the other factor that affects self-discipline among student.

\section{AUTHORS CONTRIBUTIONS}

Artha Budi Susila Duarsa, Irwan Syuhada, and Ayu Anulus were conceived, analyzed the data, discussed the results, and prepared the manuscript for the publication.

\section{ACKNOWLEDGMENTS}

In this study, all authors were grateful for the Faculty of Medicine, Al-Azhar Islamic University, Mataram, West Nusa Tenggara, Indonesia, for providing the facility and funding.

\section{REFERENCES}

[1] Kementerian Pendidikan Nasional Pengembangan pendidikan budaya dan karakter bangsa. Badan Penelit Dan Pengemb Pus Kurikulum 2010. 
[2] Permendikbud. Permendikbud RI. Peratur Menteri Pendidik Dan Kebud Republik Indones 2014:31.

[3] Gani MA. Pengaruh Disiplin Diri dan Motivasi Belajar Terhadap Prestasi Belajar Mahasiswa Akademi Maritim Cirebon. J Ilm Indones 2018;3:82-93.

[4] Abdullah R. Urgensi Disiplin Dalam Pembelajaran. Lantanida J 2015;3:18. doi:10.22373/lj.v3i1.1437.

[5] Duckworth AL, Seligman MEP. Self-discipline outdoes IQ in predicting academic performance of adolescents. Psychol Sci 2005;16:939-44. doi:10.1111/j.1467-9280.2005.01641.x.

[6] KKI. Standar Kompetensi Kedokteran Indonesia. Jakarta: Konsil Kedokteran Indonesia; 2012.

[7] Saputra O, Lisiswanti R. Faktor-faktor yang mempengaruhi keberhasilan pembelajaran keterampilan klinik di Institusi Pendidikan Kedokteran. J Kedokt 2015;5:104-9. doi:10.1063/1.4885046.

[8] Riyani Y. Faktor-faktor yang Mempengaruhi Prestasi Belajar Mahasiswa 2012;8:19-25.

[9] Sunarsi D. Pengaruh Disiplin, Motivasi, Dan Kompetensi Terhadap Prestasi Belajar (Studi Kasus Pada Mahasiswa Universitas Pamulang, Tangerang Selatan Tahun Akademik 20162017). J Mandiri 2018;1:207-26. doi:10.33753/mandiri.v1i2.19.

[10] Zimmerman BJ, Kitsantas A. Comparing students 'self-discipline and self-regulation measures and their prediction of academic achievement. Contemp Educ Psychol 2014;39:145-55.

doi:10.1016/j.cedpsych.2014.03.004.

[11] Reed CJ. Brief History and Overview of the Minnesota Multiphasic Personality Inventory (MMPI) and MMPI-2 in Psychological Assessment and The Use Of These Test In Recent Research Studies In Indonesia 2006.

[12] Hindiarti Y. Hubungan Disiplin Belajar Dengan Prestasi Belajar Mahasiswa Program Studi D-III Kebidanan Semester II Universitas Respati Yogyakarta Tahun Akademik 2012/2013. J Kesehat Bakti Tunas Husada J Ilmu-Ilmu Keperawatan, Anal Kesehat Dan Farm 2018;17:375. doi:10.36465/jkbth.v17i2.263.

[13] Moghadari-Koosha M, Moghadasi-Amiri M, Cheraghi F, Mozafari H, Imani B, Zandieh M. Self-Efficacy, Self-Regulated Learning, and Motivation as Factors Influencing Academic Achievement Among Paramedical Students: A Correlation Study. J Allied Health 2020;49:e145-52. 